\title{
THE RESILIENCE OF THE INDONESIAN BANKING SYSTEM AND MACROECONOMIC FLUCTUATION: ISLAMIC VERSUS CONVENTIONAL BANKING
}

\author{
Muh. Rudi Nugroho ${ }^{1}$, Ahmad Syakir Kurnia ${ }^{2}$, Abdul Qoyum $^{3}$ and Fitrotul Fardila ${ }^{4}$ \\ ${ }^{1}$ State Islamic University, Sunan Kalijaga, Yogyakarta, Indonesia, muhrudi.uinsuka@gmail.com \\ ${ }^{2}$ Diponegoro University, Indonesia, akhmad.kurnia73@gmail.com \\ ${ }^{3}$ State Islamic University, Sunan Kalijaga, Yogyakarta, Indonesia, qoyum13@gmail.com \\ ${ }^{4}$ State Islamic University, Sunan Kalijaga, Yogyakarta, Indonesia, fitrotulfardila1@gmail.com
}

\begin{abstract}
This study aims to analyse the challenges to the dual banking system during times of macroeconomic fluctuation. Using the default probability mapping method and macroeconomic stress testing, we measure the stability of the financial system by credit calculation. In addition, by using the stress test method, we are able to find information regarding the characteristics of the financial system in periods of crisis and its financially-related assistance in the financial system. If the financial system can detect it early, the government can take preventative measures to minimise the consequences. The results of the study show that Islamic banking has a higher default probability than conventional banking. It can therefore be concluded that the current stability of Islamic banking is no better than that of conventional banking. Our findings suggest that inflation is only a macroeconomic variable, which has a high level of sensitivity to the default probability of banks. Moreover, Islamic and conventional banking have different responses to the sensitivity of inflationary interventions.
\end{abstract}

Keywords : Probability of default, Macro-economic stress testing, Islamic financial stability, Inclusive and sustainable growth.

JEL Classification: G17; G18; G21; G28; G32.

\author{
Article history: \\ Received : : September 9, 2019 \\ Revised : October 11, 2019 \\ Accepted : April 27, 2019 \\ Available online : May 20, 2020 \\ https://doi.org/10.21098/jimf.v6i2.1135
}




\section{INTRODUCTION}

\subsection{Background}

One important lesson from the 1997-1999 and 2007-2009 crises in Indonesia was regarding the monitoring policies in the banking system. This was because the two crises brought instability to the global economy, caused by credit growth that was not monitored effectively. The rapid growth of the global financial system over the past several decades has increased the importance of appropriate measurement of the risk of distress. This needs to be done not only from a financial stability point of view, but also from a macroeconomic perspective, as financial crisis tends to have a significant and persistent negative effect on economic activity (Pedersen, 2018).

Crisis affects systemic risk mitigation, which is a major concern in maintaining financial system stability. Previous studies have employed three main approaches to measuring systemic risk in the global financial system. The first method uses direct and indirect information to aggregate country-level bilateral exposure. The second approach takes advantage of market data on credit default swap (CDS) spreads, bond spreads, and equity prices to quantify systemic risk, while the third uses simulation techniques to assess the probability of the potential contagion paths, both within and across sectors (Byrne \& Fiess, 2016).

In principle, to monitor and evaluate credit risk, the stress test method is performed to measure the potential credit risk that can occur under conditions of macroeconomic pressure. Stress tests can provide information about the characteristics of the financial system in crisis conditions and help policymakers to calculate the level of financial system vulnerability, which in turn also affects the pricing of banking products (Jones, Hilbers, \& Slack, 2004). For a decade, the International Monetary Fund (IMF) used a stress test to identify the level of vulnerability of a country's financial system. Therefore, the stress test method is very important for financial authorities to protect financial system stability from the possibility of macroeconomic turmoil (Moretti \& Stolz 2008).

It is undeniable that the success of economic development worldwide is largely supported by the performance of financial institutions or credit, which need to be effective and stable, especially in the banking industry. Studies have found that financial instability damages economic performance. As banking is a financial institution, its growth can of course be influenced by macroeconomic conditions (Brown et al., 2019). According to Ascarya and Yumanita (2009), the success of a financial system can be gauged either from its performance in allocating optimal economic resources, or from its stability in facing shocks from both the financial and macroeconomic sides. On the financial side, shocks are in the form of nonperforming loans (NPL) or non-performing finance (NPF). On the macroeconomic side, shock is caused by sharp changes in exchange rates.

According to Ajello et al. (2019), the stability of a country's financial system is strongly influenced by macroeconomic conditions. Stable conditions are reflected by high economic growth, low interest rates, and controlled inflation, which it is believed can provide a positive environment for the development of capital resources. The Central Statistics Agency (BPS) has indicated that economic growth in Indonesia has been fluctuating since 2006. For example, the inflation rate increased to $1.51 \%$ in the second quarter of 2008 , which was then followed by a 
decline in economic growth which reached $1.1 \%$ in the third quarter of 2008 . This gives an indication of the macroeconomic shock during the crisis of 2008.

Apart from the various impacts caused by macroeconomic shock, the existence of conducive macro conditions will have an impact on rising asset prices and collateral values. An increase in collateral value will in turn improve the balance sheet of banks and companies, thereby encouraging an increase in demand for and supply of credit. Furthermore, the tendency is for credit growth to increase when the economy is in an expansionary phase (boom) and to slow down when the economy is in a downward phase (bust). This phenomenon is often referred to as credit procyclicality and shows that economic growth leads to an increase in credit (Cerutti et al., 2017).

According to Alessi and Detken (2018), excessive credit growth, especially consumption credit, will trigger aggregate demand growth above potential output, which in turn can lead to inflation and an increase in interest rates. In such conditions, a possible impact is that there is a buildup of loans which have the potential to become bad loans when a boom phase in the economy ends. This may lead to the failure of debtors to fulfil their credit responsibilities, thus resulting in non-performing loans.

In some studies, research about mitigation systemic mostly remains focused on banking stability in general. Moreover, it only predicts a decrease or increase in commercial banking performance and measures the contagion risk in the banking system. Examples of such studies include those of Arpa, Giulini, Ittner, and Pauer (2001), Munich and Surya (2013), Vunjak, Milenkovic, and Andrasic (2015), Neretina \& Sahin (2015), Hoggarth et al. (2011), Foglia (2011), and Avdjiev et al. (2019). However, as in the case in Indonesia, which implements a dual banking system, research cannot be generalizsd. This is because Islamic and conventional banking naturally display different responses to shock. In fact, systemic mitigation study focused on Islamic finance is very important, especially in maintaining the growth of the Islamic financial industry.

Based on the previous studies, it would be interesting to conduct further research related to stability in such a dual banking system. Our study not only predicts decreases or increases in conventional banking performance, but also in Islamic banking performance. Moreover, the study attempts to measure the probability of default in dual banking financing using the stress testing method. Before conducting a stress test, prioritisation of the probability of default banking was made by using a credit failure ratio measurement in conventional banking and Islamic banking. The stress test method used was a test in the form of sensitivity and historical scenario test analysis. The stress test in the form of a sensitivity test was used to analyse the risk behaviour of bank financing to a single shock coming from macroeconomic variables. On the other hand, the stress test in the form of a historical scenario test was a forward-looking test used to analyse the risk behaviour of bank financing to a shock scenario under worst-case conditions.

\subsection{Objective}

The experience of the various crises that have occurred in the last two to three decades shows another side of the rapid development of the financial services 
sector, namely its vulnerability to economic turmoil, whether sourced externally or domestically. This turmoil often occurs when the financial sector is growing very rapidly, exceeding the growth of the real sector. The impact of instability is very significant and even capable of causing recession, as experienced by the global economy nearly a decade ago. Therefore, the development of the financial services sector should take place in line with the development of the real sector, or in other words, in harmony with the development of economic fundamentals. Therefore, to develop a broad Islamic economy, the stability of the Islamic financial industry must always be maintained, especially in terms of financing. Consequently, the objectives of this study include:

1. To calculate the level of the probability of default of Islamic banking financing.

2. To stress test the vulnerability of the financial system in Islamic banking amidst macroeconomic fluctuations in Indonesia.

\section{LITERATURE REVIEW}

\subsection{Background Theory}

\subsubsection{Financial Stability}

The financial system is an important part of the support for the development of the real sector. It is believed that the financial sector will always follow the real sector, with the results of financial sector development being economic growth. However, once financial system stability is achieved, it will follow the real sector situation. The financial system consists of various institutions which help bring together people's savings with others' investment (Mankiw, 1986). The financial sector plays a very important role in driving economic growth. However, many facts show that it can also be an inhibiting factor in economic development (Virtanen et al., 2018).

Many countries with poor financial systems find that it is difficult to encourage economic growth, especially for poor and developing countries. Even developed countries are also experiencing recession due to poor financial systems. Financial system stability has a direct relationship with price stability, which is a reference for monetary stability and financial sector stability, in which financial institutions and markets support the running of the overall financial system (Ajello et al., 2019). For example, if the inflation rate is high, this will encourage a tight money policy by an increase in interest rates, which can have an impact on increasing the number of non-performing loans, which in turn can cause the failure of banks and other financial institutions. Conversely, disruptions to the financial sector can affect the effectiveness of monetary policy transmission and general price levels. Nevertheless, a stable financial system will always adjust to a balanced condition after being affected by internal and external shocks. It will be able to conduct traditional functions related to efficient resource allocation, to correct price distortions, and guarantee payment systems and an adequate settlement system, all of which contribute to overall economic growth and well-being (Gadanecz \& Jayaram, 2009).

Financial stability is difficult to define and even more difficult to measure. The financial system can be categorised as stable if there is an absence of excessive volatility, stress, or crisis. This narrow definition is relatively simple to formulate, 
but fails to capture the positive contribution of a well functioning financial system to overall economic performance. Indeed, a broader definition of financial stability includes the smooth functioning of a complex relationship between financial markets, infrastructure, and institutions operating within the given legal, fiscal, and accounting framework. Such definitions are more abstract, but more inclusive of the macro-economic dimensions of financial stability and interaction between the financial and real sectors. Arzamasov and Penikas (2014) define financial stability as "a condition in which the financial system consisting of financial intermediaries, markets and its infrastructure can withstand shocks and reveal financial imbalances. Hence it can reduce the possibility of disruptions in the financial intermediation process which are severe enough to disrupt allocations savings to profitable investment opportunities significantly."

Given the imprecise nature of a broader view of financial system stability, most analysts concentrate on financial system risks and vulnerabilities, as these are relatively easy to understand and measure. However, difficulties also arise from a narrow definition, insofar as the concept of crisis is difficult to define. Various countries have been hit by different types of crisis (banking crises, currency crises, debt crises, equity crises) from time to time. There are several ways to define each type of crisis, from purely binary indicators (bank failures, suspension of debt payments by a sovereign creditor) to other quantitative variables (e.g. the number of bankruptcies, the magnitude of bank losses, GDP losses, the magnitude of exchange rate fluctuations, the decline in stock market indices). The time horizon is also important for measuring crises. Despite such problems, several attempts have been made in the literature to identify and predict crises (Ajello et al., 2019).

\subsubsection{Risk Management}

Based on the Global Risk Management Survey conducted by Delloite Development LLC (2009), risk management has always been a core competency in financial institutions. There are many definitions of it, although the concept remains the same: it deals with uncertainty. Therefore, all types of risks related to bank operations need to be managed.

Besides, the application of risk management is a necessity for the banking world in order to improve bank business performance, which is also a requirement of the Bank Indonesia regulations in Bank Indonesia Circular Letter Number $5 / 2 / D P N P / 2003$. Managing risk profiles in the process of implementing risk management in Indonesian banks is certainly not an easy task. The problem that arises is how to manage risk management in banks so that the banking intermediary function remains consistent and integrated.

Implementation of Basel II standards by focusing more on improving the quality of risk management in each risk profile is considered effective for controlling bank risk (Bank for International Settlement, 2005). However, it does not eliminate the possibility of various obstacles being faced by Indonesian banks, both directly and indirectly, which will have an impact on the effectiveness of the implementation of risk management. Eight types of risks must be managed or considered by commercial banks, one of which is credit risk. 
According to Bank Indonesia (2003), credit risk is the risk arising from the failure of the debtor and/or other parties to meet obligations to banks. In Basel II, two methods are used to measure credit risk: first, the standard approach, which uses risk weight from external ratings; and second, the internal ratings-based (IRB) approach, which allows banks to determine their measurement parameters, such as the probability of default, loss given default, and recovery rate adjusted to its credit portfolio (Bank for International Settlement, 2005).

According to Idroes (2008), risk management can be defined as a logical method and systematic in identifying, quantifying, and determining attitudes; determining solutions; and monitoring and reporting the risks that occur in each activity or process. In addition, the Law of the Republic of Indonesia Number 21 year 2008 concerning sharia banking states in article 38 paragraph 1 that risk management is a series of procedures and methodologies used by banks to identify, monitor, measure, and control risks arising from bank business activities.

Bank Indonesia has identified the general types of risk in the banking industry, which include credit risk, market risk, risk liquidity, operational risk, compliance risk, legal risk, reputation risk, and strategic risk (Usman, 2006; Ibrahim \& Rizvi, 2018). A study by Bank Indonesia concluded that in addition to banking risk in general, Islamic banking is unique in terms of its:

a. Potential for investment risk (income risk/equity investment risk), which is related to investment risk sharing when a bank enters into a partnership (syirkah);

b. Specific liquidity risk, related to differences in returns (rate of return risk) when there is a change in return expectations by the owner of the investment funds;

c. Specific market risk related to changes in inventory prices;

d. Legal specific risks associated with making transactions based on sharia principles;

e. Reputational risk, associated with meeting sharia principles in bank operations. A result of risk is direct financial loss, which it will impact on bank stakeholders, namely shareholders, employees, and customers, as well as on the economy generally.

Therefore, when dealing with various risks banks require risk management tools. In managing their risk, they are required to disclose and/or open statements by management related to the implementation of risk management. Disclosure is one of the important aspects that is considered by potential investors because it can contain an overview of the current status of the bank and projected future performance (Ali, 2006; Srairi, 2019)

\subsubsection{Financial Fragility}

Debt and financial fragility theory argues that the economy follows a cycle consisting of periods of positive and negative growth (Diamond, 2001). With economic progress, debt and risk-taking activities have increased, which creates an asset bubble that will lead to negative growth. The theory of disaster myopia posits that financial instability can be caused by the competitive behaviour of financial institutions, which leads to a condition in which the credibility of the borrower is ignored, and risk is reduced (Allen, 2004). 
The term "financial fragility" first appeared in the work of Minsky (1972). It arose during the development of his interpretation of Keynes (1936), as he sought to demonstrate the General Theory's ability to explain periods of financial instability. Financial fragility is depicted as a process that evolves over time, beginning in the trough of a business cycle. In such a trough, a technological advance in one sector of the economy pushes the rate of profit on new investment in that sector above the economic average. Investment in that sector is stimulated and, in turn, supports the demand for the output and profitability of other sectors. As profitability is restored economy-wide, the economy recovers and expands. However, as profitability is restored, firms gradually become more optimistic in their assessments of future profitability. Their valuation of liquidity declines, and they become less hesitant to use debt for financing new investment (Minsky, 1984).

Financial fragility develops in the economy, at both the micro and macro levels, as cash inflows from assets become increasingly destined to fulfil the debt service commitments generated by liabilities. Hence, an economy's resilience to shock depends upon the degree to which financial fragility has developed at the time the shock occurs. An economy that is financially robust can withstand a shock more effectively than one that is fragile. The cyclical performance of the economy and the conditions conducive to crisis are generated by the collective behaviour of individual firms with respect to their investment and financing decisions. Recently, New Keynesians have begun to provide the economics and policy communities with a discourse on "financial fragility," without any reference to where this term originated (Nasica, 2000).

\subsection{Previous Studies}

The impact of instability is very significant and even capable of causing recession, as experienced by the global economy nearly a decade ago. Therefore, the development of the financial services sector should take place inline with the development of the real sector; in other words, in harmony with the development of economic fundamentals. Financial instability makes systemic risk mitigation a major concern in maintaining overall financial stability.

Research related to the measurement of financial system stability using the stress test method has been conducted by both agencies and researchers. The research conducted by Arpa, Giulini, Ittner, and Pauer (2001) entitled "The Influence of Macroeconomic Developments on Austrian Banks: Implication for Bank Supervision," found that real GDP growth, interest rates, and trade have a significant effect on NPL.

Related research was also conducted by Munich and Surya (2013) in their paper entitled "Stress-Testing the Indonesian Economics by on Its Macroeconomic Variables (An Analysis of Firm-Wide Probability of Default)." The results of the study indicate that exchange rates have a positive and significant effect on the probability of default, while the BI rate has a negative and significant effect on the variable probability of default. Their results also show that there were simultaneous influences of macroeconomic variables on the default probability of each company covered in each economic sector.

Research by Vunjak et al. (2015) focused on measuring the effects of the economic crisis on the capital adequacy ratio (CAR), concluding that 14 of the 
30 banks analysed had variations in capital above the average capital adequacy ratio. With 43 considerations of central bank scenarios, $50 \%$ of problem loans were not paid back. Vunjak et al. noted that $47 \%$ of the banks analysed need to take significant measures regarding the increase in provisions for decreasing loans in the following year, to cover this risk and to avoid the operation of dangerous banks that were affected by the financial crisis. Banks also had to reduce the number of loans in risky marked. However, if they wanted to increase lending in the sector, banks needed to be careful, not exceed $10 \%$ of total bank portfolio loans , and ensure reserves for these loans.

Sahin et al. (2020) studied the effect of banking stress tests on returns and risks. They conducted a stress test on US banks regarding the price of bank equity, credit risk, and systemic risk during the 2009-2015 period. The findings of their study indicate that the publication of stress test results posed a systemic risk to banks, as indicated in 2009 and 2013. The study concluded that stress tests could reduce systemic risk. Overall, it can be concluded that stress tests generate valuable information for the market and can play a role in alleviating bankruptcy. In other words, stress tests are useful tools for dealing with systematic and systemic risks in the stock and credit markets.

Nevertheless, all these previous studies mostly focus on banking stability in general. In the case in Indonesia, however, which implements a dual banking system, research cannot be generalised. This is because Islamic and conventional banking will have different responses to issues in the market. Hence, to develop a broad Islamic economy, the stability of the Islamic financial industry must always be maintained, especially in terms of financing.

The difference between this study and previous research is that it combines several models, mapping the probability of default using credit failure ratios, and measuring the level of financial system vulnerability and the failure rate of sectoral banking financing using the stress testing method. With regard to the stress testing method, analytical tools were used in the form of logistic regression and ARIMA. Moreover, the study not only focuses on banking stability in general, but also attempts to analyse Islamic banking stability.

\section{METHODOLOGY}

\subsection{Data}

Based on the nature of the data, a quantitative research approach was adopted, whereby the conclusions are drawn based on data processed through quantitative calculation methods to explain the impact of macroeconomic variables on the probability of default of banks in Indonesia, both conventional and Islamic. Considering that Indonesia is a country that implements a dual banking system, the research objects are conventional and Islamic banking, including conventional and Islamic commercial banks. Specifically, the objects are classified into seven conventional banks and two Islamic banks.

Quarterly data from 2006 to 2017 were employed in the study. The data were obtained from published Indonesian banking statistics, the Indonesian Central Statistics Agency, and central bank publications. They include data on default probability, GDP growth, exchange rates, inflation, and the CSPI over the period 
2006-2017. This timescale is analogous to events before and after the global financial crisis of 2008. The data were used as a historical analysis base for the stress tests, mainly for conducting event analysis, to ascertain whether the variables referred to severe or moderate conditions.

\subsection{Model Development}

The analytical method used to measure the probability of bank default was the non-performing finance ratio, adopted from the research of Munich and Surya (2013). In their study, they adopted the default risk model of Ong (1999), which assumes that default risk refers to the uncertainty of a company in terms of its ability to meet all its obligations to debtors and obligors. Because the main concern of credit problems is related to the concept of default risk, this study uses nonperforming finance, total loans, and probability of default as measures of the risk of their failure. Because the probability of default is bound to loan problems, it is possible to analyse it based on NPF divided by total base loans (Munich \& Surya, 2013). The calculation formula is as follows:

$$
P D=\frac{N P F}{L_{i}}
$$

where PD is default probability, namely the probability of the borrowers' failure to fulfil their obligations/return the loan; NPF is nonperforming finance; and $\mathrm{Li}$ is the total loan.

According to Central Banks, a company is considered to have a potential threat to its business if it has a problem ratio of $5 \%$. Because this study considers the probability of default, if this probability is $>5 \%$, then the company is declared to be in default. However, because this study also aims to establish the potential for possible default, a company is declared to be in a warning or potential default condition when its probability of default is $>4 \%{ }^{1}$

In addition, this study also tests the impact of macroeconomic variables on the probability default, with the following formula²:

$$
\begin{aligned}
& \text { Probabilty of Default }=\operatorname{Ln}\left(\frac{P_{t}}{1-P_{t}}\right)=\beta_{0}+\beta_{1} G D P_{t}+\beta_{2} \text { ExchangeRate }_{t}{ }^{+} \\
& \beta_{2} \text { Inflasi }_{t}+\beta_{4} \text { IHSG }_{t}
\end{aligned}
$$

\subsection{Method}

The basic models and assumptions for use in stress tests continue to be debated. Current stress test practices, however, are not based on a set of systematic and comprehensive principles, but emerge from trial-and-error and often reflect human, technical, and data constraints. Notwithstanding this, the stress test method has proven to be effective in testing the stability of financial institutions (Borio et al.,

\footnotetext{
1. The researcher assumed that when the probability of default is higher than $4 \%$, it is declared to be in a warning or potential default condition. Because this research aims to mitigate mitigate what?, this scenario was designed to create a cautionary or early warning signal about banking stability.

2. Model developed from the logistic regression model.
} 
2011). Most research models used in stress test analysis are vector autoregression (VAR)/the vector error correction model (VECM), and logistic regression.

However, in this study the stress test method used is the macro stress test, by which the stability of financial institutions is tested simultaneously, which has an impact on the economy as a whole. The analysis model used is a logistic regression model. The purpose of using the logit model is to establish the probability of certain variables influencing banking stability in Indonesia over a certain period.

The additional macroeconomic term in stress testing means that macroeconomic variables are included in the testing process. The inclusion of these is related to the process that describes a macroeconomic situation that can cause a plausible event, which will then be emphasised in the response, which is default probability (Munich \& Surya, 2013).

The analysis model in this study used a logistic regression model. The purpose of using the logit model is to find out how much the probability of certain variables in influencing the stability of the economic sector in Indonesia in a certain period of time. The logit model is a way of quantifying the relationship between the probability of two choices with certain selected characteristics. In addition, the logit regression model is a regression model used to analyse the dependent variable with a possibility of between 0 and 1 . It can then be concluded that the dependent variable in the logit model is a discrete variable (dummy variable) that is of value 1 and 0 , while the independent variables are non-discrete. In this research, PD has a value of 0 when its value is $<=4 \%$, and of 1 if its value is $>4 \%$.

The general equation of logistic regression with as many independent variables ask is as follows:

$$
\mathrm{L}=\ln \left(\frac{P i}{1-P i}\right)=\beta_{0}+\beta_{1} X_{1 i}+\beta_{2} X_{2 i}+\ldots .+\beta_{k} X_{k i}
$$

According to Virtanen et al. (2018), the above equation can be interpreted as follows:

1. $\mathrm{L}$ is linear in $\mathrm{X}$.

2. $\mathrm{L}$ is also linear in $\beta \_1$ and $\beta \_2$.

3. $\mathrm{L}$ is called the Logit model.

4. Because $P$ lies between 0 and 1 , L lies between $-\infty$ and $\infty$.

5. Although $\mathrm{L}$ is linear in $\mathrm{X}, \mathrm{P}$ is not linear in $\mathrm{X}$.

7. $\quad \beta \_0$ states the odds ratio when $X$ is zero.

6. $\quad \beta \_1$ represents the change in $L$ when $X \_1$ changes 1 unit.

\section{RESULTS AND ANALYSIS}

\subsection{Results}

\subsubsection{Probability of Default Mapping Results in the Indonesian Banking System} Before further analysing the resilience of Islamic banks to macroeconomic shock, mapping of the probability of default was first conducted. Such mapping aims to establish the outline of banking stability in both conventional and Islamic banks and to observe the default rate level for each type of bank in a certain period. In this study, the probability of banking default is estimated using the credit failure ratio 
model approach. A summary of the results of the probability of default estimation in Indonesian banks using this approach are shown in Table 4.1.

Table 1.

Average Probability of Default Values in Indonesian Banking, 2006-2017

\begin{tabular}{llcc}
\hline & Bank Classification & Average PD & PD \\
\hline & Bank_Persero & 0.049 & 0.035 \\
& BUSN_Devisa & 0.025 & \\
& BUSN_Non Devisa & 0.024 & \\
Conventional Banks & BPD & 0.023 & \\
& Bank_Campuran & 0.023 & \\
& Bank_Asing & 0.037 & \\
& BPR & 0.067 & 0.056 \\
\multirow{2}{*}{ Islamic Banks } & Bank_Syariah & 0.040 & \\
& BPRS & 0.073 & \\
\hline
\end{tabular}

Source: Data Calculation Results, 2019

From Table 1, it can be seen that the highest average probability of default of conventional banking in Indonesia occurs in rural banks, with a probability of default of $4.9 \%$, while the lowest average occurs in the group of mixed banks, at $2.3 \%$. As for Islamic banking over the past 10 years, there is a probability of default of $4 \%$ in Islamic banks (Bank Syariah) and $7.3 \%$ in Islamic rural banks (BPRS). These figures are fairly high, considering that Islamic banks are well-known for their resilience to crisis, but the fact is that they have a higher risk of financial failure when compared to the average probability of default of conventional banks.

In broad outline, and based on the results of the estimated probability of default conducted on the two Islamic banks and seven conventional ones, the average probability of default values obtained were as follows:

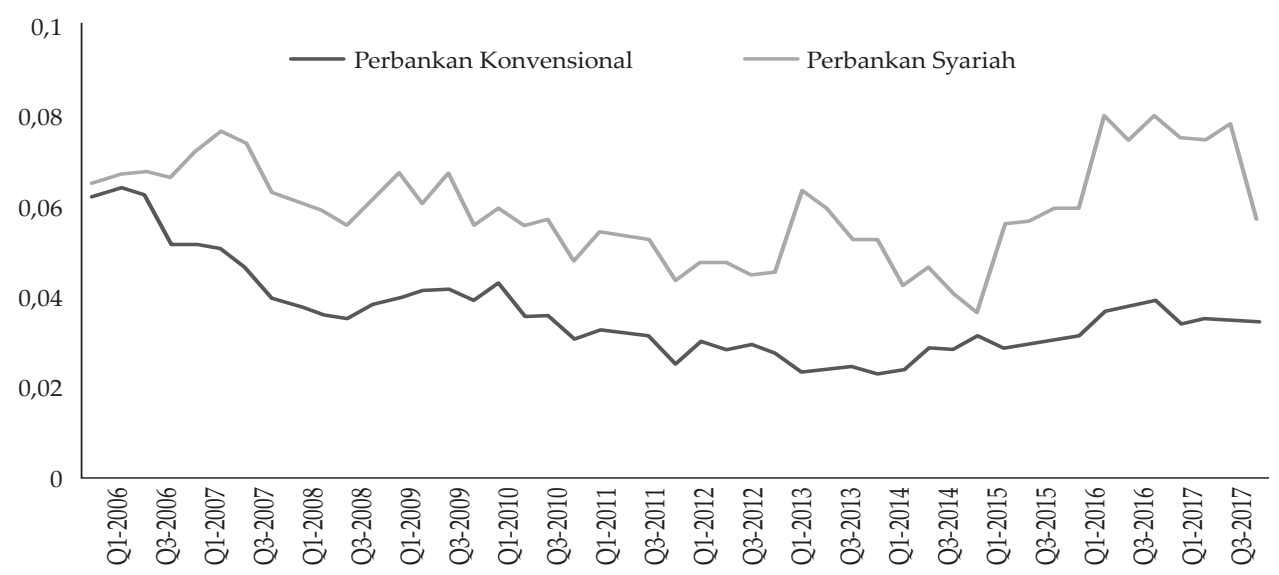


Figure 1 shows the movement of the average values of the probability of default of the sample Islamic and conventional banks. In general, the average value for Islamic banking is in the range of $3.5 \%$ to $6.5 \%$, while for conventional banking it is in the range of $2 \%$ to $6 \%$. The line of movement of the average probability of default for conventional banking is below that of Islamic banking, which means that from its credit ratio the former is more stable than the latter. This is because the average probability of default of conventional banking is lower than that of Islamic banking.

\subsubsection{Macroeconomic Stress Testing Against the Probability of Default in the Indonesian Banking System}

A p-value test was conducted to obtain a set of macroeconomic variables that would be chosen to construct the model, as described in the procedures in the estimation section. The selected macroeconomic variables were statistically significant. Based on the results of the logistic regression of each bank, as shown in Table 2, it can be concluded that the four macroeconomic variables have partially different effects on each bank. Positive and negative signs on each variable affect the probability of default in parallel. A positive sign indicates a direct relationship between the independent variable and the dependent variable, while a negative sign indicates the opposite relationship.

Table 2.

Logistic Regression Results on the Four Macroeconomic Variables to PD in the Indonesian Banking System

\begin{tabular}{lccccc}
\hline \multicolumn{1}{c}{$\begin{array}{c}\text { Variable } \\
\text { Bank Category }\end{array}$} & C & GDP & Ex_Rate & Inflation & CSPI \\
\hline State-owned Banks & 76.41 & 2.79 & 0.86 & 2.32 & $(-9.50)$ \\
Prob. & 0.17 & 0.15 & 0.85 & $0.03^{*}$ & $0.01^{*}$ \\
BUSN Devisa & 155.18 & $(2.98)$ & $(13.23)$ & $(0.53)$ & $(3.44)$ \\
Prob. & 0.26 & 0.19 & 0.38 & 0.72 & $0.02^{*}$ \\
Regional Development Banks & 22.74 & $(5.34)$ & 15.39 & $(0.81)$ & 12.72 \\
Prob. & 0.76 & 0.35 & 0.11 & 0.49 & $0.04^{*}$ \\
Mixed Banks & 53.38 & $(0.84)$ & $(1.48)$ & $(3.35)$ & $(4.22)$ \\
Prob. & 0.37 & 0.67 & 0.82 & 0.13 & $0.01^{*}$ \\
Foreign Banks & 49.81 & 1.45 & $(1.06)$ & 0.51 & $(4.44)$ \\
Prob. & 0.14 & 0.29 & 0.74 & 0.42 & $0.01^{*}$ \\
Rural Credit Banks & 35.32 & 4.83 & 4.47 & 0.47 & $(8.49)$ \\
Prob. & 0.29 & $0.05^{*}$ & 0.29 & 0.52 & $0.01^{*}$ \\
Islamic Banks & $(126.98)$ & 4.01 & 5.76 & 1.82 & $(2.61)$ \\
Prob. & $0.01^{*}$ & $0.05^{*}$ & $0.00^{*}$ & $0.04^{*}$ & $0.01^{*}$ \\
Islamic Rural Financing Banks & 80.79 & 7.71 & 7.13 & 0.78 & $(15.96)$ \\
Prob. & 0.20 & 0.19 & 0.32 & 0.50 & $0.02^{*}$ \\
\hline
\end{tabular}

* significant at $95 \%$

( ) negative signs

Source: Eviews9, 2019 
The computed p-values, both in causal and simultaneous relations, show the small possibility that $\mathrm{H} 0$ is almost not true for each variable, depending on the bank. Based on the calculations, only the CSPI has a statistically significant confidence level overall, at $95 \%$. This phenomenon is related to the CSPI itself, which is a variable that cannot be controlled, and moves according to market conditions. As for the other variables, GDP is only significant in two banks, namely rural credit banks and Islamic banks; the exchange rate is only significant for Islamic banks; and inflation is only significant in state-owned and Islamic banks.

By using the results of the logistic regression, stress tests could be conducted. There were two stages of macroeconomic stress testing: the first was analysis of risk behaviour for a shock (sensitivity test); and the second analysis of risk behaviour in a simultaneous shock scenario (hypothetical test analysis). The advantage of sensitivity testing is that there is only one shock variable, so it will be easier to implement. However, a sensitivity test on a single form may be unreasonable, because under stress it cannot be influenced by only one key variable. Therefore, hypothetical test analysis was also conducted.

According to Hoggarth et al. (2005), hypothetical test analysis is an analysis of scenarios that makes more sense in stress testing, because it not only uses one key variable, but also examines the impact of changing several key variables. The variables used in this analysis are macroeconomic ones that have been tested significantly on each probability of banking default. However, before projecting the probability of default, baselines and scenarios were set when preparing the stress tests, based on the movements of each macroeconomic variable (Munich \& Surya, 2013). In this study, the baseline used was the movement of macroeconomic variables and curve-fitted from the 4th quarter of 2019 to the 4th quarter of 2020. The curve-fitting technique uses a different approach to each variable; Table 3 shows the curve-fitting method for each of the macroeconomic variables.

Table 3. Curve-fitting Technique Based on Theil's U and RMSE

\begin{tabular}{lccc}
\hline \multicolumn{1}{c}{ Method } & Variable & Theil's U & RMSE \\
\hline ARMA $(1,1)$ & X1 & 0.46 & 0.29 \\
ARIMA $(3,1,1)$ & X2 & 1.00 & 1047.88 \\
ARMA $(2,2)$ & X3 & 0.35 & 0.54 \\
AR $(3)$ & X4 & 1.00 & 2664.79 \\
\hline
\end{tabular}

Source: Data Calculation Results (Eviews9), 2019

The curve-fitting technique is based on the lowest root mean square error (RMSE) value. Because the value of Theil's U ranges from 0.35 to 1.00, this shows the flexibility to use assumptions that fit the curve. A greater Theil's U value indicates that the curve-fitting technique can be used as an assumption. Based on this technique, Table 4 presents the curve-fitted macroeconomic variables. 
Table 4.

Curve-Fitted Macroeconomic Variables

\begin{tabular}{ccccc}
\hline \multirow{2}{*}{ Kuartal } & X1 & X2 & X3 & X4 \\
\cline { 2 - 5 } & GDP & Ex_Rate & Inflasi & CSPI \\
\hline 2019Q4 & 1.39 & 9.70 & 1.45 & 0.03 \\
2020Q1 & 1.39 & 9.71 & -0.93 & 0.03 \\
2020Q2 & 1.39 & 9.72 & 150 & 0.03 \\
2020Q3 & 1.39 & 9.73 & -1.04 & 0.03 \\
2020Q4 & 1.39 & 9.74 & 1.55 & 0.03 \\
\hline
\end{tabular}

Source: Data Calculation Results (Eviews9), 2019

\subsection{Analysis}

4.2.1. Macroeconomic Stress Testing Analysis of the Indonesian Banking System The use of historical scenarios in this study is useful as a benchmark for what occurred in the 1997-1998 and 2007-2009 crises in Indonesia. Each movement of the macroeconomic variable data based on the crisis thus becomes a severe or moderate scenario when conducting the macroeconomic stress tests. Based on the historical movements, the movement of the Composite Stock Price Index (CSPI) closing price data shows severe conditions in 2007-2009 and moderate conditions in 1997-1999. In 2008 there was a global financial crisis marked by the bankruptcy of several large companies in the United States, which was triggered by the housing credit crisis and securities products. The crisis affected the Indonesian economy, one of the indicators being the fall in share prices on the capital market. The CSPI of the Indonesia Stock Exchange (IDX) decreased sharply by $50.64 \%$, from 2.745 in 2007 to 1.355 in 2008.

Even though the CSPI subsequently rose in the long run, in certain years, it fell. Between 1997 and 2017, it fell six times, namely in 1997, 1998, 2000, 2001, 2008, 2013 and 2015. Between 1997 and 2001, it experienced a fall almost every year, as Indonesia was hit by the crisis monetary. In 2008, the CSPI fell once again due to the effects of the global crisis of that year, while in 2013 and 2015 it fell because the national economy began to experience a slow down after the continuing expansion of the previous 10 years.

The movement of the CSPI data is used as the main scenario in this study. This also refers back to the results of the logistic regression, which showed that all PD banks, both conventional and Islamic, are significant to shocks on the CSPI variable, so the CSPI was used as the main variable in the stress test scenario. As Chorafas (2002, p. 14) notes, "lots of great analysts have been using fixed estimates of how much ultimately the shock, but in fact, it is a dynamic variable."

This is slightly different from the results of a previous study conducted by Munich \& Surya (2013), which found that the CSPI and exchange rate variables were key variables in the stress test scenario, as well as of the study of Arpa, Giulini, Ittner, \& Pauer (2001), who found GDP growth to be a key variable. With regard to this study, only one key variable was found, namely the CSPI. As seen in Table 2, the results of the logistic regression of the four macroeconomic variables indicate that the CSPI variable is significant for the default probability of all banks. 
In this study, therefore, the CSPI is the key variable in the stress testing scenario. The difference in the results is partly due to differences in the observation period; in previous studies the period only covered the 1997-1999 and 2008-2009 crises. However, this research focuses on observation of the 2008-2009 crisis, as well as the economic turmoil of 2012-2013 and 2015. In addition, the object of observation in the different studies is different. While previous research focused on the probability of default at the sectoral level, this study is more focused on banking itself.

Testing the stress of economic growth and inflation is conducted by calculating the shock variable based on existing historical data. Therefore, the calculation of shock itself will change the initial data into shock based on movement, not the value as the CSPI and exchange rate variables.

Table 5.

Stress Test Probability of Default Banking under Severe CSPI Conditions

\begin{tabular}{cccccccccc}
\hline Q & 1X4 & 2X4 & 3X4 & 4X4 & 5X4 & 6X4 & 7X4 & 8X4 & 9X4 \\
\hline 2019Q4 & 0.004 & 0.030 & 0.024 & 0.262 & 0.060 & 0.254 & 0.257 & 0.336 & 0.768 \\
2020Q1 & 0.004 & 0.030 & 0.024 & 0.262 & 0.060 & 0.254 & 0.257 & 0.336 & 0.768 \\
2020Q2 & 0.004 & 0.030 & 0.024 & 0.262 & 0.060 & 0.254 & 0.257 & 0.336 & 0.768 \\
2020Q3 & 0.004 & 0.030 & 0.024 & 0.262 & 0.060 & 0.254 & 0.257 & 0.336 & 0.768 \\
2020Q4 & 0.004 & 0.030 & 0.024 & 0.262 & 0.060 & 0.254 & 0.257 & 0.336 & 0.768 \\
\hline
\end{tabular}

Source: Data Calculation Results (Eviews9), 2019

From Table 5, it can be seen that the great shock on X4 holds the most significant changes in the stress testing probability of bank default. From this, it follows that the CSPI is the main concern in monitoring the possibility of bank defaults. Based on the calculations made on the nine banks comprising the stress test sample, five were very exposed to the risk of CSPI shocks:, namely regional development banks (BPD); foreign banks; conventional rural banks (CRB); Islamic banks; and Islamic rural banks (IRB). The remainder were less affected by severe shock occurring in the CSPI. What is meant by "default" here is the possibility of bank financing failure. A high CSPI indicates good, stable banking performance. Consequently, an increase in it will lead to a decrease in the probability of bank financing failure.

Table 5 illustrates the probability of bank default when the CSPI is in a severe mode, as happened in the crisis of 2007-2008. The worst conditions will be experienced by the IRB; when the CSPI falls to $50 \%$ of its previous valuation value, the probability of default occurring in the IRB is 70\%. The most important aspect of stress testing is the risk of banking openness to any shock conditions that occur. A good stress test must be accompanied by a good and applicable implementation plan (mitigation). The existence of a second-round effect must be reviewed to obtain the best mitigation (Munich \& Surya, 2013). Conducting stress testing as a tool in risk management to identify events that make sense rarely occurs but can have a disastrous impact, the monetary and banking policy authorities can prepare their mitigation plans properly. It therefore follows that the monetary and banking policy authorities need to monitor CSPI risk closely, as the probability of default by all banks is related to the risk of CSPI growth. 
Regarding the findings of this study, when the CSPI value is most influential, even though it cannot be controlled, the only action based on the significant variables in each bank is to conduct inflation interventions, whose ultimate goal is to stabilise the monetary and banking system. The findings show that inflation has a significant enough coefficient to influence the probability of default, so intervention could be considered. Referring to Table 4, the figures are evaluated by using the baseline rather than inflation. If no interventions are made, regional development banks, foreign banks, conventional rural banks, Islamic banks, and Islamic rural banks will have a probability of default greater than 0.20 in the period from the fourth quarter of 2019 to the fourth quarter of 2020. The banks with the highest default position are the IRB, whose probability of default will be greater than 0.50 in the period from the fourth quarter of 2019 to the fourth quarter of 2020.

The Indonesian government of course needs to put maximum effort into solving economic problems. Interventions are bound to be made, but to what extent should these take place to bring about economic stability? This question is always an interesting one, especially in this case. Given the role of government in stabilising the economy, specific approaches can be taken, but are often constrained by other limits of the policy effect. This study ignores these specific constraints and focuses on optimising the probability of default. Table 6 shows the results of the sensitivity test on inflation against the probability of default of banks under the pressure of poor CSPI conditions.

Table 6.

Inflation Sensitivity Test

\begin{tabular}{cccccccccc}
\hline \multirow{2}{*}{ Inflation } & \multicolumn{10}{c}{ Banks } \\
\cline { 2 - 10 } & $\mathbf{1}$ & $\mathbf{2}$ & $\mathbf{3}$ & $\mathbf{4}$ & $\mathbf{5}$ & $\mathbf{6}$ & $\mathbf{7}$ & $\mathbf{8}$ & $\mathbf{9}$ \\
\hline $0 \%$ & 1,2 & 1,8 & 1,1 & 1,2 & 1 & 1,4 & 1,6 & 1,4 & 2,1 \\
$1 \%$ & 1,4 & 1,8 & 1,1 & 1,2 & 1,1 & 1,8 & 1,7 & 1,5 & 2,1 \\
$2 \%$ & 1,5 & 1,9 & 1,1 & 1,2 & 1,1 & 2,3 & 1,8 & 1,5 & 2,1 \\
$3 \%$ & 1,7 & 1,9 & 1,1 & 1,2 & 1,1 & 3 & 2 & 1,6 & 2,1 \\
$4 \%$ & 1,9 & 1,9 & 1,1 & 1,2 & 1,1 & 4 & 2,1 & 1,6 & 2,1 \\
$5 \%$ & 2,1 & 1,9 & 1,1 & 1,2 & 1,2 & 5,2 & 2,2 & 1,6 & 2,1 \\
\hline
\end{tabular}

Source: Data Calculation Results (Eviews9), 2019

Based on Table 6, it can be seen the results of an analysis of inflation sensitivity tests on the probability of banking defaults under the pressure of a bad CSPI condition. The table demonstrates that a lower inflation rate will send the impact of a shorter default period, regardless of how sensitive the change is. From these results, it can be seen that banks 1, 6 and 7, namely the state-owned, foreign, and conventional rural banks respectively, are very sensitive to intervention. On the other hand, banks 2, 5 and 8, the national private (BUSN), foreign exchange, mixed, and Islamic banks, are less sensitive or less affected by inflation intervention. In addition, banks 3, 4 and 9, namely non-foreign exchange BUSN, regional development (BPD), and Islamic rural financing banks, appear to be completely unaffected by any inflation intervention that the government makes. 
Regarding the findings of the study, where the IHSG value is the most influential, even though it cannot be controlled, the only action based on the significant variables in each bank is to conduct inflation interventions, whose ultimate goal is to stabilise the monetary and banking system. The findings show that inflation holds a large enough coefficient to influence the probability of default financing in banks, so intervention could be considered. But what happens if an inflation-based intervention only has a positive impact on conventional banking and an adverse effect on Islamic banking? Based on the results of the sensitivity tests on inflation for the next few periods (Table 6), it can be seen that the effects of inflation policy do not have a good impact on Islamic banking. Interventions for inflation through various monetary policies have in fact only stabilised the conventional monetary and banking system.

\section{CONCLUSION AND RECOMMENDATIONS}

\subsection{Conclusion}

Based on the results of the mapping of the probability of default, it has been found that such probability in Islamic banking is greater than that in conventional banking. With regard to the movements in the average value of Islamic and conventional banking, Islamic banking is in the range of $3.5 \%$ to $6.5 \%$, while conventional banking is in the range of $2 \%$ to $6 \%$. The line of movement of the average value of conventional banking is below that of the average value of Islamic banking, which means that conventional banking seen from the credit ratio is more stable than Islamic banking. This is because the average conventional banking is smaller than Islamic banking.

In addition, based on the results of the macroeconomic stress tests on banks in Indonesia, the overall picture shows that their condition is unstable. It was found that inflation is a macroeconomic variable with a high level of sensitivity to banking stability. A relatively stable inflation rate of below 5\% should reflect a low level of probability of bank default. This is because with a low inflation rate, the expansion of the real sector should be strong, meaning bank liquidity is also smooth. However, with inflation conditions that are classified as low and stable, economic conditions are sluggish (in a bust condition), and the probability of default in banks is also quite high.

The inflation sensitivity test results show that when an intervention policy is implemented against inflation, only conventional banks are sensitive in responding to these changes. On the other hand, Islamic banking did not respond appropriately to changes in inflation as a result of monetary policies that were implemented.

The study concludes that to maintain the growth of Islamic banking, systemic mitigation is needed that is focused on its current condition. Mapping the probability of default and macroeconomic stress tests are strategies that can be used in maintaining such growth. Differences in behaviour between Islamic and conventional banking result in different effects when responding to policies. Therefore, the follow-up and intervention of both must be assessed from both sides, namely from the perspectives of Islamic and conventional banking. Additionally, Islamic banking cannot grow and remain stable if the policies and mitigations provided are the same as for conventional banking. 


\subsection{Recommendations}

A number of recommendations are made. For the regulator, it is very important to pay more attention to the movement of variables that are indicated to disrupt financial stability in banks in Indonesia. Based on this study, Islamic banking has a higher default probability; therefore, it need special treatment from the regulator to identify and mitigate risk and to ensure its stability is better than that of conventional banking, as stated by many theories.

On the practical side, the study suggests that mapping the probability of default and macroeconomic stress tests can be used as strategies to maintain the growth of the Islamic banking industry. In addition, it is very important that Islamic banking practitioners identify financial stability along with macroeconomic fluctuation.

For future research, it is suggested that another model could be used to detect default probability, such as the Merton model. In addition, to obtain more convincing results, further studies could use a longer data, in the different horizon of time, especially by splitting time periods based on crisis or non-crisis conditions.

\section{REFERENCES}

Ajello, A., Laubach, T., López-Salido, D., \& Nakata, T. (2019). Financial Stability and Optimal Interest Rate Policy. International Journal of Central Banking, 2019, 279-326.

Alessi, L., \& Detken, C. (2018). Identifying Excessive Credit Growth and Leverage. Journal of Financial Stability, 35, 215-225. https://doi.org/10.1016/j.jfs.2017.06.005.

Ali, M. (2006). Manajemen Risiko Strategi Perbankan dan Dunia Usaha Menghadapi Tantangan Globalisasi Bisnis,. PT. Raja Grafindo Persada. give a translation into English of the title, in square brackets, after the original.

Allen, F. D. G. (2004). Financial Fragility, Liquidity, and Asset Prices. Journal of the European Economic Association.

Arpa, M., Giulini, I., Ittner, A., \& Pauer, F. (2001). The Influence of Macroeconomics Developments on Austrian Banks: Implication for Banking Supervision,. BIS Paper No. 1, Basel: BIS Press \& Communications.

Arzamasov, V., \& Penikas, H. (2014). A Financial Stability Index for Israel. Procedia Computer Science, 31, 985-994. https://doi.org/10.1016/j.procs.2014.05.351.

Ascarya \& Yumanita., D. (2009). The Formulation of Financial Stability Index and The Role of Islamic Banking in The Indonesian Dual Banking System. Bank Indonesia Working Paper Series 11/2009, PPSK Bank Indonesia. (2009).

Avdjiev, S., Giudici, P., \& Spelta, A. (2019). Measuring Contagion Risk in International Banking. Journal of Financial Stability. https://doi.org/10.1016/j. jfs.2019.05.014.

Borio, C., Drehmann, M., \& Tsatsaronis, K. (2011). Stress-testing Macro Stress Testing: Does It Live Up To Expectations? Bank for International Settlements. November.

Brown, S., Gray, D., \& Montagnoli, A. (2019). Credit Supply Shocks and Household Leverage: Evidence from the US Banking Deregulation. Journal of Financial Stability, 43, 97-115. https://doi.org/10.1016/j.jfs.2019.06.002. 
Byrne, J. P., \& Fiess, N. (2016). International Capital Flows to Emerging Markets: National and Global Determinants. Journal of International Money and Finance, 61, 82-100. https://doi.org/10.1016/j.jimonfin.2015.11.005.

Cerutti, E., Claessens, S., \& Laeven, L. (2017). The Use and Effectiveness of Macroprudential Policies: New Evidence. Journal of Financial Stability, 28, 203-224. https://doi.org/10.1016/j.jfs.2015.10.004.

Chorafas, D. N. (2002). Debts and the Use of Models in Evaluating Credit Risk. In D. N. Chorafas (Ed.), Modelling the Survival of Financial and Industrial Enterprises: Advantages, Challenges and Problems with the Internal Ratingsbased (IRB) Method (pp. 91-112). Palgrave Macmillan UK. https://doi. org/10.1057/9780230501737_5.

Diamond, D. R. R. (2001). Liquidity Risk, Liquidity Creation, and Financial Fragility: A Theory of Banking. The Journal of Political Economy.

Ferry N Idroes. (2008). Manajemen Risiko Perbankan, Pemahaman Pendekatan 3 Pilar Kesepakatan Basel II Terkait Aplikasi Regulasi dan Pelaksanaannya Di Indonesia, 2008. In Jakarta: PT. RajaGrafindo Persada.

Foglia, A. (2011). Stress Testing Credit Risk: A Survey of Authorities' Approaches. SSRN Electronic Journal, volume/issue? 9-45. https://doi.org/10.2139/ ssrn.1396243.

Gadanecz, B., \& Jayaram, K. (2009). Measures of Financial Stability - A Review. Irving Fisher Committee (IFC) - Bank for International Settlements (BIS), 31, 365380. https://doi.org/10.1086/663992.

Hoggarth, G., Sorensen, S., \& Zicchino, L. (2005). Stress Tests of UK Banks Using a VAR Approach (SSRN Scholarly Paper ID 872693). Social Science Research Network. https://papers.ssrn.com/abstract=872693.

Hoggarth, G., Sorensen, S., \& Zicchino, L. (2011). Stress Tests of UK Banks Using a VAR Approach. SSRN Electronic Journal, 282. check format https://doi. org/10.2139/ssrn.872693.

Ibrahim, M. H., \& Rizvi, S. A. R. (2018). Bank Lending, Deposits and Risk-Taking In Times of Crisis: A Panel Analysis of Islamic and Conventional Banks. Emerging Markets Review, 35, 31-47. https://doi.org/10.1016/j.ememar.2017.12.003.

Jones, M. T., Hilbers, P., and Slack, G. (2004). Stress Testing Financial Systems: What to Do When the Governor Calls, Washington: IMF Working Paper.

Mankiw, N. (1986). The Allocation of Credit and Financial Collapse. Quarterly Journal of Economics, 101(3), 455-70.

Minsky, H. (1984). Frank Hahn's Money and Inflation: A Review Article. Journal of Post Keynesian Economics, 6(3), 449-57.

Moretti, Marina., Stephanie Stolz, dan M. Swinburne (2008). Stress Testing at the IMF. IMF Working Paper.JEL Classification: G10, G20.

Munich, A., \& Surya, B. A. (2013). Stress-Testing The Indonesia Economic Sectors by Shock on ITS Macroeconomic Variable (An Analysis of Firm-Wide Probability of Default). Indonesian Journal of Business Administration, 2(2), 137-151.

Nasica, E. (2000). Finance, Investment and Economic Fluctuations: An Analysis in the Tradition of Hyman Minsky. Cheltenham: Edward Elgar.

Neretina, E., C. Sahin, and J. D. H. (2015). Banking Stress Test Effects on Returns and Risks,. Working Papers, SSRN. 
Ong, M. K. (1999). Internal Credit Risk Model. London: Risk Books.

Pedersen, M. (2018). Credit Risk and Monetary Pass-Through-Evidence from Chile. Journal of Financial Stability, 36, 144-158. https://doi.org/10.1016/j. jfs.2018.03.005.

Sahin, C., Haan, J. de, \& Neretina, E. (2020). Banking Stress Test Effects on Returns and Risks. Journal of Banking \& Finance, 105843 https://doi.org/10.1016/j. jbankfin.2020.105843.

Virtanen, T., Tölö, E., Virén, M., \& Taipalus, K. (2018). Can Bubble Theory Foresee Banking Crises? Journal of Financial Stability, 36, 66-81. https://doi.org/10.1016/j. jfs.2018.02.008.

Vunjak, N., Milenković, N., Andrašić, J., \& Pjanić, M. (2015). Stress Test Model for Measuring the Effects of the Economic Crisis on the Capital Adequacy Ratio. Acta Polytechnica Hungarica, 12(5). https://doi.org/10.12700/ APH.12.5.2015.5.10. 